\title{
Seroprevalence of dengue virus antibodies in asymptomatic Costa Rican children, 2002-2003: a pilot study ${ }^{1}$
}

\author{
Roberto Iturrino-Monge, ${ }^{2}$ Maria L. Avila-Agüero, ${ }^{2}$ Claudio R. Avila-Agüero, ${ }^{3}$ \\ Tatiana Moya-Moya, ${ }^{4}$ Alejandro Cañas-Coto, ${ }^{2}$ Kattia Camacho-Badilla, ${ }^{2}$ \\ and Betzana Zambrano-Mora ${ }^{5}$
}

\begin{abstract}
Objectives. Since 1993 dengue has become more frequent in Costa Rica. Adults have been the most affected population, while children have remained virtually unharmed. So far no studies have investigated how many asymptomatic children have been affected by this virus. This pilot study documents the seroprevalence, measured as the presence of IgG antibodies, of dengue virus in asymptomatic children from two different geographical areas.

Methods. This descriptive, prospective epidemiologic study compared the presence of antibodies in children who live in a coastal region of a tropical country where dengue is endemic, and an inland area where dengue is not endemic. An enzyme-linked immunosorbent assay was used to test the serum for dengue virus IgG antibodies. None of the children had a prior history of dengue, fever, immunosuppressive therapy or underlying disease.

Results. During the period from July 2002 to July 2003, 103 children were recruited from each area. In the costal region we found a seroprevalence of $36.9 \%$. In the inland area seroprevalence was $2.9 \%$.

Conclusions. We found a substantial number of asymptomatic infections in Costa Rican children. This greatly increases the risk of dengue hemorrhagic fever or dengue shock syndrome in these children, in whom previous dengue infection had gone undetected. Preventive efforts should be targeted at the costal region due to the higher prevalence in this area.
\end{abstract}

Key words Children, dengue, hemorrhagic fever, Costa Rica.

\footnotetext{
1 Presented in part as an abstract at the 43rd Interscience Conference on Antimicrobial Agents and Chemotherapy, Chicago, Illinois, United States of America, September 2003, abstract No. G-1554. No reprints available.

2 Pediatric Infectious Diseases Division, Hospital Nacional de Niños, San Jose, Costa Rica. Send correspondence to: Maria L. Avila-Agüero, MD, Head of Pediatric Infectious Diseases Division, Hospital
}

Nacional de Niños, San Jose, Costa Rica; telephone and fax: (506) 258-2173; e-mail: avilaaguero@ gmail.com

3 Clinical Laboratory, Hospital Monseñor Sanabria Puntarenas, Costa Rica.

4 Clinical Microbiology Laboratory, Hospital Nacional de Niños, San Jose, Costa Rica.

5 Clausen Laboratories, Montevideo, Uruguay.
Dengue fever was first described in 1779; the viruses that cause the disease are transmitted in nearly all tropical countries (1-5). About two thirds of the world's populations live in areas infested with dengue virus vectors, mainly Aedes aegypti. Currently, all 
four dengue viruses circulate simultaneously in some areas. It is estimated that up to 80 million people become infected annually in the world, and this figure is probably higher due to marked underreporting (6-7).

In 2001 more than 609000 cases of dengue were reported in the Americas alone; of these, 15000 corresponded to dengue hemorrhagic fever (DHF). In tropical areas such as Costa Rica, dengue transmission increases during the rainy season. In October 1993 Costa Rica reported the circulation of type 1 dengue virus (DENV-1), and in 1994 the other serotypes were reported. The first case of DHF was reported in 1995 (8). Since 1999 the number of dengue cases observed in Costa Rica has increased, with more than 6000 cases being reported that year. In 2000 the number dropped to less than 4000 cases. In 2001 and 2002, the numbers of reported cases were 9237 and 12 251, respectively, and by the year 2003, 15000 cases of classic dengue had been reported (6-9). Currently, serotypes 1 and 2 circulate in different areas of Costa Rica.

In the last 10 years dengue has spread widely throughout Latin America. The mosquito A. aegypti has taken advantage of increased urbanization rates and crowding to transmit the virus (4). The causes of this recrudescence are multiple, and include increases in the numbers of infected and susceptible human hosts, strains of dengue virus, and size of mosquito population. Also involved are changes in feeding habits, time from infection to infective state, the likelihood of virus transmission from human to mosquito to human, and temperature. Temperature affects vector distribution, size, feeding habits, and extrinsic incubation period. In this connection, it is notable that Costa Rica has been affected by population growth and unplanned urbanization. Also, some authors have predicted that San José, Costa Rica and Taxco, México are the two cities where dengue fever will affect the most inhabitants, since $A$. aegypti is now found at higher altitudes due to global warming $(3,10)$.

The dengue virus can produce clinical symptoms that vary from a mild, self-limited fever which can be subdiagnosed or misdiagnosed, to severe illness known as hemorrhagic dengue $(3-4,11)$. Age is an important variable in the outcome of secondary dengue infection. Case fatality and hospitalization rates are higher in young infants and the elderly. The risk of death in a child during a second dengue infection is nearly 15 times higher than in adults, probably due to increased microvascular permeability $(3,12,13)$.

Until now there have been no studies to investigate the incidence of dengue virus antibodies in the asymptomatic pediatric population in Costa Rica; therefore these results will provide vital information to health services. The aim of this prospective, descriptive, pilot study was to document recent or past dengue infection in asymptomatic children with no previous history of dengue infection by establishing seroprevalence, measured as the presence of IgG antibodies. This study was done in two different regions in Costa Rica: one where the incidence of dengue virus infection and circulation rates are high (the coastal city of Puntarenas), and another where the incidence and circulation rates are low (the inland city of San José).

\section{MATERIAL AND METHODS}

This prospective, open, descriptive, noninterventional epidemiologic study compared dengue antibody seroprevalence in children of 1 year to 10 years 11 months of age in two areas of Costa Rica. Puntarenas, the largest costal province (population 358137 inhabitants), is located in the southwestern region of the country on the Pacific coast. The capital city San José (population 1 373000 inhabitants) is located $115 \mathrm{~km}$ inland, at an altitude of $1150 \mathrm{~m}$. Serum samples were collected during a 12month period between July 2002 and July 2003 at two national hospitals, one in the costal region and one in the inland region. The study was approved by the Bioethics and Research Committee of the Dr. Carlos Sáenz Herrera National Children's Hospital (file UBIHNN-025-2002) and by authorities of the Monseñor Sanabria Hospital in Puntarenas. Informed consent was signed by a parent or legal guardian before clinical samples were taken.

Two hundred six children were included (103 in each region). Sample size was calculated with the formula

$$
\begin{gathered}
N=\frac{z^{2} \times p(1-p)}{d^{2}}= \\
\frac{1.98 \times 0.05(1-0.05)}{0.0009}=103
\end{gathered}
$$

where $p$ corresponds to the estimated prevalence of dengue in the population $(5 \%), d$ is the error rate $(3 \%)$, and $z$ was estimated as $95 \%$.

The patients were classified according to age into 10 groups, with each group corresponding to children aged (for example) 1 year to 1 year 11 months. Children in the oldest age group were therefore from 10 years to 10 years 11 months old.

The inclusion criteria were age 1 year to 10 years 11 months, permanent residence in the coastal or inland region, absence of fever for at least 72 hours prior to inclusion, and informed consent signed at least by one of the parents or legal representatives. The exclusion criteria were history of yellow fever vaccination or disease, history of dengue disease with serological confirmation, known immunodeficiency, immunosuppressive treatment during the previous month (including corticosteroids for more than 4 weeks), and fever (axillary temperature $\geq 37.5^{\circ} \mathrm{C}$ ) at the time of recruitment.

One 3-mL blood sample was taken by venous puncture in all children to obtain serum. The blood sample was centrifuged for $10 \mathrm{~min}$, aliquoted and stored at $-20{ }^{\circ} \mathrm{C}$ until processed. The PanBio Dengue IgG enzyme-linked immunosorbent assay (ELISA) (14) (PanBio, Brisbane, Australia) was used to detect dengue virus IgG antibodies. This ELISA is able to distinguish all 4 dengue serotypes, and also distinguishes primary from secondary dengue infection. The methods and reagents were used in accordance with the manufacturer's recommendations. No control assays were performed with the kit. 
TABLE 1. Positivity for dengue antibodies in 206 Costa Rican children in a coastal region and an inland area in 2002-2003

\begin{tabular}{lcc}
\hline Age group (years/months) & Costal region (No.) & Inland area (No.) \\
\hline $1 / 0-1 / 11$ & 0 & 0 \\
$2 / 0-2 / 11$ & 2 & 0 \\
$3 / 0-3 / 11$ & 1 & 0 \\
$4 / 0-4 / 11$ & 5 & 0 \\
$5 / 0-5 / 11$ & 1 & 0 \\
$6 / 0-6 / 11$ & 4 & 1 \\
$7 / 0-7 / 11$ & 5 & 0 \\
$8 / 0-8 / 11$ & 4 & 1 \\
$9 / 0-9 / 11$ & 7 & 1 \\
$10 / 0-10 / 11$ & 9 & 0 \\
Total & 38 & 3 \\
\hline
\end{tabular}

The test results were interpreted according to the manufacturer's guidelines as Panbio units (PU) of absorbance in the sample, as follows: negative, < 9 PU; indeterminate, 9-11 PU; positive, > 11 PU. According to the manufacturer's guidelines, values greater than $40 \mathrm{PU}$ are associated with secondary dengue.

The seroprevalence rate and 95\% confidence intervals (CI) were calculated for each region. Differences between the two regions were established with the chi-squared test and $z$ approximation.

\section{RESULTS}

Two hundred six children aged 1 year to 10 years 11 months old were included; 150 (73\%) of them were boys. In the coastal sample, antibodies for dengue virus IgG were found in 38 of the 103 children (36.9\%; 95\% CI $27.55 \%-46.15 \%)$. The median score was 30.7 PU (range 16-49). Seven cases $(6.8 \%)$ of secondary dengue infection were identified by PU values $\geq 40$. In the inland region only 3 children were positive $(2.9 \%$; $95 \%$ CI $0.00 \%-$ $6.21 \%$ ). The median score was $26.3 \mathrm{PU}$ (range 16-36.6). We identified no cases of secondary dengue in this inland population sample. The seroprevalence of IgG dengue antibodies in each age group is shown in Table 1.

The chi-squared test to check for differences in proportions yielded 37.30, and the $z$ approximation to compare proportions yielded 6.18. The difference $(95 \% \mathrm{CI})$ between coastal and inland groups was considered statistically significant at $P<0.05$.

\section{DISCUSSION}

This is the first report on dengue seroprevalence in asymptomatic Costa Rican children. The seroprevalence found in the inland region (San José, $2.9 \%$ ) was in accordance with the estimated prevalence of $5 \%$. (The prevalence was arbitrarily reckoned since at the time the study was carried out, no prevalence data were available.) Nevertheless, seroprevalence in the coastal region (36.9\%) was higher than expected. There is a need to establish the incidence and vulnerability of both populations in order to develop public health strategies. Our data for prevalence can be useful for establishing sample size more accurately, and for conducting larger studies of similar characteristics.

Since $A$. aegypti has become highly domesticated and feeds during the daytime, as children grow older they are exposed to the vector for a longer period of time. Even though cases of dengue have been reported in the costal region in children younger than 6 years, the incidence shows a tendency to rise after this age. One plausible explanation is that children begin formal schooling at this age. This means that children (who usually attend public schools) are away from home for longer. The location of school buildings is important: most of them are located in government property, which tends to be less well cared for than residential properties. Potential sources of dengue mosquitoes are thus easy to find in public school buildings and their surroundings. This highlights the importance of concentrating mosquito control programs in areas where children spend more time.

The coastal region has been an area of high incidence since the beginning of the dengue outbreaks in Costa Rica. However, most cases have been reported in adults. Considering the number of seropositive children in the coastal region, it can be inferred that considerable exposure to the disease has also affected children. Asymptomatic seropositive children in whom a previous episode of dengue went undetected are at risk for developing hemorrhagic dengue instead of classic dengue. Because the risk of morbidity and mortality is increased in children, secondary dengue in seropositive children must be prevented in order to avoid deaths. This is significant because in most other prospective studies, all patients who were hospitalized for dengue suffered secondary dengue infections (15-18). Interestingly, 7 children in our study experienced secondary infections, but none of them were hospitalized. Graham and others (1) described similar findings. 
Another interesting result was the finding of 3 positive cases in the inland area, previously considered naïve because of its altitude $(>914 \mathrm{~m})$. None of these patients had a history of disease or travel to an endemic area. This raises the possibility of dengue outbreaks in this region, consistent with recent reports of the presence of the mosquito at altitudes as high as $2012 \mathrm{~m} \mathrm{(3-12).} \mathrm{This}$ reflects the ability of $A$. aegypti to adapt to new environments, and the potential for the epidemic to spread in cities at similar or higher altitudes.

Although we used an ELISA that also detects cross-reacting antibodies to other flaviviruses such as yellow fever virus, most of the positive samples are likely to represent true dengue infections. This is so because yellow fever has been eradicated in Costa Rica and the yellow fever vaccine is not included in the National Immunization Pro- gram. Other limitations of the study are the small sample size and preliminary nature of the findings. Thus, the results should be interpreted with caution, and more data are necessary.

In conclusion, seroprevalence was shown to differ between a coastal and an inland region due to greater exposure to the vector in the former area. The number of asymptomatic dengue infections is alarming because these children may be susceptible to DHF even though they have never had a known episode of classic dengue. Moreover, the appearance of dengue infection in an area considered naïve to the disease calls for new vector control strategies. Vector control is currently the strongest weapon against dengue epidemics; however, a licensed dengue vaccine is not yet available for children.

If exposure to the vector is maintained in the coming years, children in
Costa Rica are likely to develop DHF and dengue shock syndrome. Although dengue infection is more serious in children, our preliminary work as reported here is one of the first pediatric epidemiological studies of this disease. Countries with dengue epidemics should be encouraged to investigate seroprevalence rates to verify the findings in this study.

Acknowledgments. We would like to thank Olga Arguedas-Arguedas, Head of the Bioethics and Research Committee of the Dr. Carlos Sáenz Herrera National Children's Hospital, and Rolando Ulloa-Gutierrez of the Pediatric Infectious Diseases Division of the National Children's Hospital, for critical review of the manuscript, and Hugo Dibarboure for his assistance in the preparation of this study.

\section{REFERENCES}

1. Graham RR, Juffrie M, Tan R, Hayes CG, Laksono I, Ma Roef $\mathrm{C}$, et al. A prospective seroepidemiologic study on dengue in children four to nine years of age in Yogyakarta, Indonesia I. Studies in 1995-1996. Am J Trop Med Hyg. 1999;61:412-9.

2. Guzmán MG, Kourí G. Dengue: an update. Lancet. 2002;2:33-42.

3. Halstead SB, Rigau-Perez JG, Gubler DJ. Is there an unapparent dengue explosion? Lancet. 1999;353:1100-1.

4. Lifson AR. Mosquitoes, modes and dengue. Lancet. 1996;347:1201-2.

5. Guzman MG, Kouri G. Dengue and dengue hemorrhagic fever in the Americas: Lessons and challenges. J Clin Virol. 2003;27:1-13.

6. Gubler DJ. Epidemic dengue/dengue hemorrhagic fever as a public health, social and economic problem in the 21st century. Trends Microbiol. 2002;10:100-3.

7. Anonymous. Dengue in Central America: The epidemics of 2000. Epidemiol Bull. 2000;21:4-8.

8. Sáenz E, Víquez M, Lara J. Vigilancia virológica del dengue en Costa Rica: octubre de 1993-septiembre de 1996. Semana Epidemiol. 1996; 41:6-12.

9. Anonymous. Dengue fever in Costa Rica and Panama. Epidemiol Bull. 1994;15:9-10.

10. Epstein PR. Is global warming harmful to health? Sci Am. 2000;283:50-7.

11. Gubler DJ, Clark GG. Dengue/dengue hemorrhagic fever: the emergence of a global health problem. Emerg Infect Dis. 1995;1:55-7.

12. Herrera-Basto E, Prevots DR, Zarate ML, Silva JL, Sepulveda-Amor J. First report outbreak of classical dengue fever at 1,700 meters above sea level in Guerrero State, Mexico, Jun 1988. Am J Trop Med Hyg. 1992;46:649-53.

13. Halstead SB. Dengue. Curr Opin Infect Dis. 2002;15:471-6.

14. Cuzzubbo AJ, Vaughn DW, Nisalak A, Solomon T, Kalayanarooj S, Aaskov J, et al. Comparison of PanBio Dengue Duo IgM and IgG capture ELISA and venture technologies dengue IgM and IgG dot blot. J Clin Virol. 2000;16:135-44.

15. Sangkawibha N, Rojanasuphot $S$, AhandriK $S$, Viriyapongse S, Jatanasen S, Salitul V, et al.
Risk factors in dengue shock syndrome: a prospective epidemiological study in Rayong, Thailand. Am J Epidemiol. 1984;20:653-69.

16. Thein S, Aung MM, Shwe TN, Aye M, Zaw A, Aye K, et al. Risk factor in dengue shock syndrome. Am J Trop Med Hyg. 1997;56:566-72.

17. Winter PE, Yuill TM, Udomsakdi S, Gould D, Natapanich S, Russell PK. An insular outbreak of dengue hemorrhaghic fever. I Epidemiological observations. Am J Trop Med Hyg. 1968;17:561-73.

18. Halstead SB. Immunological parameters of togavirus disease syndromes. In: Schlesinger RW, ed. The togaviruses. New York: Academic Press, Pp. 107-73.

Manuscript received on 29 June 2005. Revised version accepted for publication on 20 June 2006. 
RESUMEN Objetivos. Desde 1993, la frecuencia de dengue en Costa Rica ha venido aumentando. La población de adultos ha sido la más afectada, mientras que en los niños apenas se han presentado casos. Hasta el momento no se han realizado estudios para determinar cuántos niños asintomáticos se han visto afectados por el virus de la enfermedad. Este estudio piloto documenta la seroprevalencia de anticuerpos de tipo IgG contra el virus del dengue en niños asintomáticos procedentes de dos zonas geográficas distintas.

Métodos. En este estudio epidemiológico descriptivo y prospectivo se comparó la presencia de anticuerpos en niños que vivían en la zona costera de un país tropical donde el dengue es endémico, y en una zona del interior donde no lo es. Se usó inmunoadsorción enzimática para detectar IgG en el suero. Ninguno de los niños tenía antecedentes de dengue, enfermedad febril, tratamiento inmunosupresor o enfermedad subyacente.

Resultados. Durante el período transcurrido desde julio de 2003 hasta julio de 2003, se reunió a 103 niños de cada área. En la zona costera encontramos una seroprevalencia de IgG de 36,9\%; en el interior, de 2,9\%.

Conclusiones. Encontramos muchos casos de infección asintomática por el virus del dengue en niños costarricenses. Esto conlleva un riesgo elevado de fiebre hemorrágica del dengue o de síndrome de choque por dengue en estos niños en quienes la infección había pasado inadvertida. Es necesario tomar medidas preventivas en la región del litoral debido a la mayor prevalencia de la enfermedad en ella.

Palabras clave Niño, dengue, fiebre hemorrágica, Costa Rica.

\section{Dengue y dengue hemorrágico en las Américas: guías para su prevención y control}

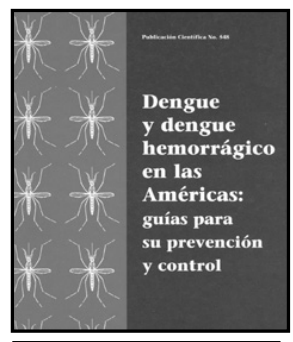

$1995 \cdot 116 \mathrm{pp}$.

ISBN 9275315485 Código: PC 548

Precio: US\$25.00/

US\$ 18.00 en América Latina y el Caribe
Las pautas presentadas en esta publicación subrayan el hecho de que el dengue es un problema vinculado principalmente con el saneamiento del medio domiciliario. Los vectores más importantes del dengue, Aedes aegypti y Aedes albopictus, se pueden controlar mediante maniobras físicas y sin el uso excesivo de sustancias químicas. A diferencia de los antiguos programas centralizados y de estructura vertical, estas pautas hacen hincapié en las distintas formas de transferir a la comunidad la responsabilidad, capacidad y motivación que requieren el control y la prevención del dengue.

La presente publicación, que ha sido preparada por 18 representantes de siete países de las Américas y varios funcionarios de la OPS, todos expertos en el tema tratado, ocupa un lugar crítico en la lucha contra el dengue y constituye un instrumento indispensable para profesionales de la salud que participan en el control de vectores.

Usted también puede enviar su pedido y pago en dólares estadounidenses a: http://publications.paho.org Fax: (301) 206-9789・E-mail: paho@pmds.com•Oficina de la OPS/OMS en su país. 